\title{
Rapid assessment of marketing of unhealthy foods to children in mass media, schools and retail stores in Oman
}

\author{
Samia Al-Ghannami, ${ }^{1}$ Saleh Al-Shammakhi, ${ }^{1}$ Ayoub Al Jawaldeh, ${ }^{2}$ Fatma Al-Mamari, ${ }^{1}$ Ibtisam Al Gammaria, ${ }^{1}$ Jokha Al-Aamry ${ }^{1}$ and Ruth Mabry ${ }^{3}$
}

${ }^{1}$ Department of Nutrition, Ministry of Health, Muscat, Oman. ${ }^{2}$ World Health Organization Regional Office for the Eastern Mediterranean, Cairo, Egypt. ${ }^{3}$ World Health Organization Representative Office, Muscat, Oman. (Correspondence to: Ruth Mabry: rmmabry@gmail.com).

\begin{abstract}
Background: The prevalence of overweight and obesity is high in the Eastern Mediterranean Region. Half of the Region's adult women $(50.1 \%)$ and more than two in five men $(43.8 \%$ ) are overweight or obese, and $6.9 \%$ of children aged under five years in the Region are already overweight, which is higher than the global average of $6.2 \%$.

Aims: This rapid assessment aimed to examine marketing techniques of foods and non-alcoholic beverages targeting children and assessed implementation of food restrictions in schools as part of the national effort to address obesity in Oman.

Methods: Trained reviewers assessed Arabic TV satellite stations, local radio and print media, a random sample of schools, and a convenience sample of grocery stores, cafes and convenience stores between November 2015 and October 2016.

Results: A majority of TV advertisements (71\%) were for follow-up milk formula and used a variety of methods to attract children. A large portion of radio advertisements (44\%) were for savoury snacks; all included children and used sounds/ words to attract children. Few print media advertisements promoted snacks; however, a large majority of the sugary snack advertisements (13\% of print media) used pictures/words and incentives (awards) to attract children. In schools, most beverages purchased by children had added sugars.
\end{abstract}

Conclusions: Establishing a comprehensive regulatory framework under the national Child Law and the Convention of the Rights of the Child should be complemented by systematic monitoring of their impact on child health, and increasing food and beverage literacy among principals, teachers, canteen managers and the wider community.

Keywords: Nutrition policy, children, school policy, media, Oman

Citation: Al-Ghannami S; Al-Shammakhi S; Al-Jawaldeh A; Al-Mamari F; Al-Gammaria I; Al-Aamry J; et al. Rapid assessment of marketing of unhealthy foods to children in mass media, schools and retail stores in Oman. East Mediterr Health J. 2019;25(11):820-827. https://doi.org/10.26719/emhj.19.066

Received: 19/01/18; accepted: 02/12/18

Copyright (C) World Health Organization (WHO) 2019. Some rights reserved. This work is available under the CC BY-NC-SA 3.0 IGO license (https:// creativecommons.org/licenses/by-nc-sa/3.0/igo).

\section{Introduction}

The prevalence of overweight and obesity is high in the Eastern Mediterranean Region. Half of the Region's adult women $(50.1 \%)$ and more than two in five men $(43.8 \%)$ are overweight or obese. About $6.9 \%$ of children aged under five years in the Region are already overweight, which is higher than the global average of $6.2 \%$ (1). Moreover, the rate is even higher for children in countries of the Gulf Cooperation Council (GCC; Bahrain, Kuwait, Oman, Qatar, Saudi Arabia and the United Arab Emirates) (2). Obese children are at higher risk of experiencing breathing difficulties and fractures, have early markers for cardiovascular disease, insulin resistance and mental health issues (3,4). Additionally, obesity in children has a direct impact on quality of life and educational attainment. In the long-term, childhood obesity is associated with an increased risk of adult obesity, cardiovascular disease, and diabetes (3).

Addressing childhood obesity is part of the Wold Health Organization (WHO) Global Plan on Noncommunicable Diseases (NCDs), which aims for a $25 \%$ reduction in overall mortality from cardiovascular disease and a halt in the rise of diabetes and obesity by 2025 (5). Childhood obesity is a complex combination of factors and is difficult to unravel. Restricting marketing of unhealthy foods and non-alcoholic beverages to children is a key intervention advocated by the Commission on Ending Childhood Obesity (6); detailed recommendations were endorsed by the World Health Assembly in 2010 to facilitate the implementation of the Global Plan (6). In his message during a high-level meeting on noncommunicable diseases in July 2014, then UN Secretary-General Ban Ki-Moon called on the private sector to stop marketing unhealthy foods to children (7). During the same year, the Eastern Mediterranean Regional Committee urged Member States, "to protect public health and promote healthy lifestyles, with a special focus on countering the largely unopposed commercial practices that promote unhealthy food products, particularly those targeting children" (8). This was reiterated in the Montevideo Roadmap in late 2017 (9).

Clear evidence shows that marketing practices of the food and beverage industry influence children's choices and contribute to childhood obesity $(6,10)$. A recent systematic review confirmed that food promotion can impact children's knowledge, food preferences, purchase behaviours, and food consumption (10). The marketing of foods and beverages has been identified as an important modifiable determinant for children's health. At the regional level, the investment in marketing by the food 
and beverage industry is increasing, consists largely of unhealthy food and beverages, and targets children. For example, television advertising of sugar-sweetened drinks on regional television channels targeting children is ubiquitous, peaking during after-school hours (11). Yet, countries have been relatively slow in implementing the WHO marketing recommendations. The food industry has a responsibility to stop marketing unhealthy foods to children, including older children and adolescents (12). Based on these facts and as signatories of the Convention of the Rights of the Child (CRC), governments of the GCC have an obligation to protect and fulfil the right of the child to the enjoyment of the highest attainable standard of health, the right to adequate food, and several other related children's rights $(13,14)$.

Only three studies have examined the extent of obesity in children in Oman. A 2004 local study of 550 students noted the higher rates of overweight/obesity in older children; rates were highest among $15-16$ years olds (boys: 24.8\%, girls: 19.3\%) (15). The 2017 National Nutrition Survey reported that $25.7 \%$ of girls aged $15-19$ years were overweight/obese. Much higher rates were found in the 2015 Global School Health Survey (GSHS), a national survey of 13-17 year old students (boys: $39.7 \%$ and girls: $43.2 \%$ ) (16). Although data from the national school surveillance programme shows lower rates than those in these studies, they confirm higher rates in older children (Grade 1: 5.8\%, Grade 7: 16.4\%, Grade 10: 18.5\%) (17). Given this trend and the high consumption of sugary drinks in adolescents (boys: $48.6 \%$, girls: $36.1 \%$ ) and other unhealthy dietary practices, obesity in children is an increasing concern $(16,18,19)$.

Understanding causal factors is difficult to determine due to the complexity of the issue and limited local evidence. Despite the paucity of information, policymakers are keen to address these unhealthy dietary practices and childhood obesity including strengthening the Omani regulatory framework on marketing practices in line with global and regional commitments. This rapid assessment aims to assess the marketing techniques targeting children in mass media, schools and food outlets and the implementation of food restrictions in schools in Oman.

\section{Methods}

\section{Sample selection}

The sample for this rapid assessment included five Pan-Arab satellite stations perceived to be the most popular with children (Baraem, Cartoon Network, $\mathrm{MBC}_{3}$, Noon and Toyur Al Ganna) and all six national radio channels (Al Wisal, English FM, General, Hala FM, Hi FM and Quran). Newspapers may be an additional source of exposure of children to food and beverage advertisements. The most widely-read Arabic and English dailies (Al Ro'ya, Al Shabeeba, Al Watan, Oman Daily, Oman Observer, and Times of Oman) (20) and weekly newspapers and magazines published in Oman (Al Waseet, Futoon, and The Week) including Majid Magazine, the only print media targeting children, were reviewed. Using a sampling frame of 1100 government schools in 11 governorates (21), a random sample of five schools from each governorate were selected in cooperation with the Ministry of Education (MoE). A convenience sample of three convenience stores/coffee shops within 500 metres from one selected school in each governorate plus one major grocery store were also selected.

\section{Data collection and analysis}

Trained reviewers assessed advertisements from television and radio programmes from one work day and one weekend day (8:00 to 22:00 hours) between November 2015 to January 2016 totalling 308 broadcast hours (television [TV]: 140 hours, radio: 168 hours). Print media published from 7 November 2015 to 17 January 2016 were also reviewed. Trained regional nutrition focal points visited the selected schools and food outlets from February to October 2016 following approval from the MoE.

Assessment tools were developed separately for mass media, schools and retail stores. Advertisements in mass media (TV, radio, newspapers) were reviewed to identify the most common products advertised and the marketing techniques used (i.e., presence of children, celebrity and/or a cartoon character, catchy music, childrelated activities or toys). In schools, administrators were asked about the management of the school canteens, knowledge about MoE restrictions on food sold in school canteens and corporate sponsorship of school-based activities. Canteen managers were asked about their awareness about the MoE regulations and to recall the most common items sold to students. Nearby food outlets were visited to determine whether students were frequent customers and if so, to identify the most common foods and beverages sold to them. Major grocery stores were assessed to identify products and marketing strategies used to target children. All food and drinks identified in the different settings were grouped according to the 18 categories of the Nutrient Profile developed by the WHO Office for the Eastern Mediterranean Region (22).

Completed questionnaires were reviewed for quality and checked for missing information. Data entry was carried out using EpiData software. Data management and univariate and bivariate analysis were carried out on SPSS software 16.

\section{Results}

\section{Mass media}

A total of 792 advertisements from the three types of mass media were reviewed (Table 1); a majority (58.2\%) were TV advertisements (ads) followed by newspaper (32.6\%). The types of food advertised varied by media; $71.4 \%$ of TV ads were for follow-up milk formula while $63.2 \%$ of newspaper ads were related to convenience foods. Midday TV shows included the highest proportion of ads (71\% of a total of 461 ads). Almost all television ads (72.7\%) were between children's programmes (Table 2). A small portion $(14.5 \%)$ were for sugary items including choco- 


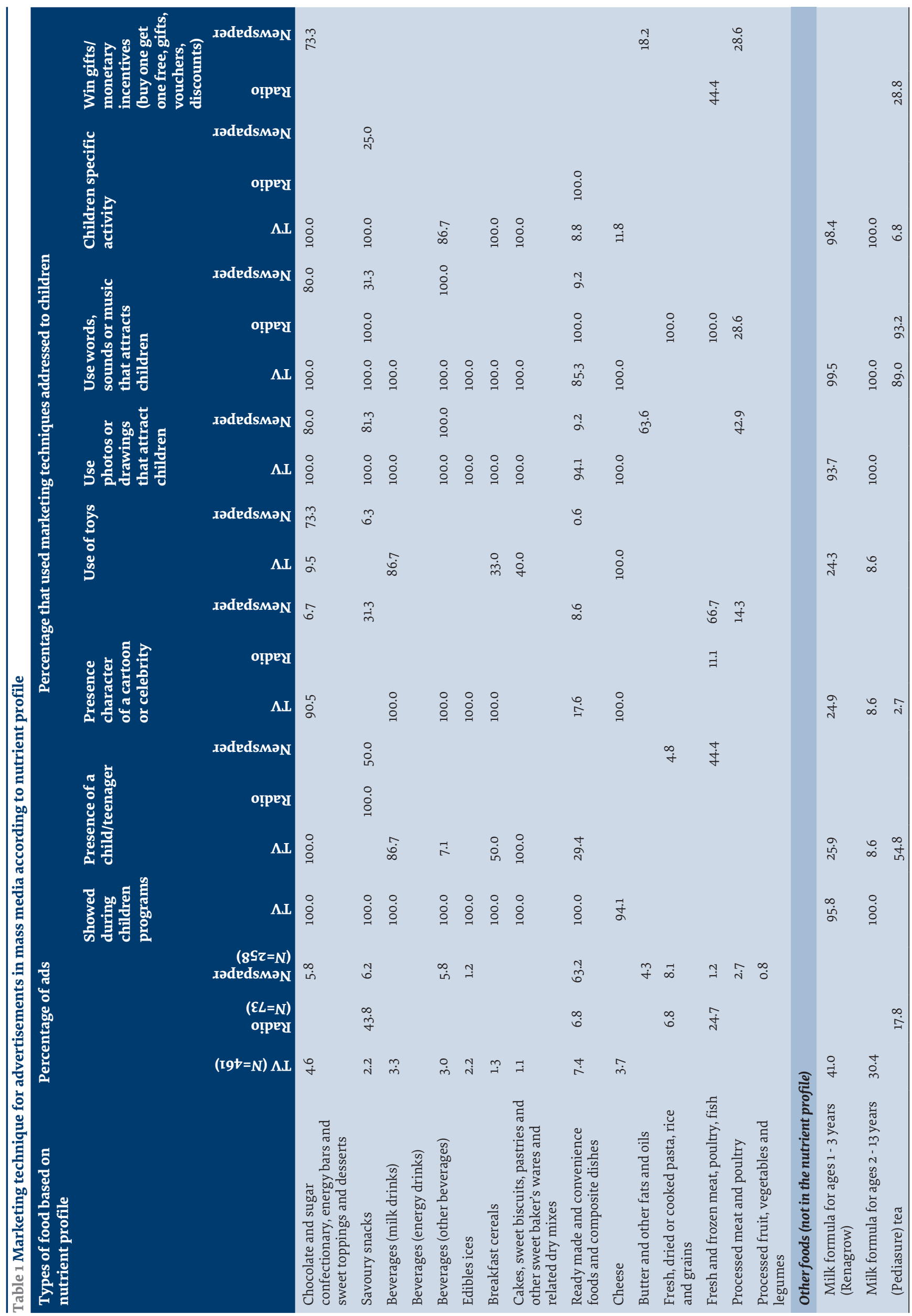


late and other confectionaries (4.6\%), milk drinks (3.3\%), other beverages $(3.3 \%)$ and edible ices $(2.2 \%)$. Numerous techniques to attract children were used. Follow-up milk formula ads, the most common product advertised on TV, used sounds/music to attract children $(100 \%)$, portrayed child-friendly activities (98-100\%), were shown during children's programmes (96-100\%), and used pictures that would attract children (94-100\%).

Reviewers assessed 73 radio advertisements from 73 radio programmes targeting children. Nearly half of them were for savoury snacks ( $44 \%$ ) and $25 \%$ were for fresh and frozen meats and poultry; none were for sugary food and drinks. Children were present in $100 \%$ of the ads for the savoury snacks; in addition, all sounds, music and words were used that would attract children and adolescents.

Nearly half of the print media advertisements $(52 \%$ of 258) reviewed were found in the Times of Oman; another quarter were in Al Shabiba (25.6\%). Most of these advertisements were in supplements to the paper including sports $(27.9 \%)$, advertisements $(21.7 \%)$ and economic (17.8\%). Most ads (63.2\%) were for ready-made and convenience foods using minimal techniques to attract children. $12.8 \%$ were for sugary products including sweets such as chocolates $(5.8 \%)$, other beverages $(5.8 \%)$ and edible ices (1.2\%). For ads related to chocolate and other confectionaries, $80 \%$ used pictures and/or words attractive to children and $73 \%$ used toys and/or awards attractive to children.

\section{Schools and food outlets}

Fifty-six primary and preparatory schools, including single-sex and mixed schools, were assessed. School canteens operated in four different modes. The most common was for a catering company to lease the space (51.8\%); other modalities were: contracting a catering company selected by the regional Directorate of School Education (21.4\%), contracting a company by the school administration (19.7\%), or leasing the space by a community member through the Sanad programme (a government small business initiative) (5.5\%).

The awareness of school principals and canteen managers on the restrictions on types of products sold in the canteen varied. All schools principals and canteen managers were aware of the ban on the sale of soft drinks in schools, and a good majority $(>80 \%)$ were aware of the restrictions on other items (Table 3). The level of awareness was markedly lower for some food items including various types of pastries, sweets, chocolates and traditional desserts (principals: $64.3 \%, 78.6 \%, 76.8 \%$ and $78.6 \%$; canteen managers: $62.5 \%, 75.0 \%, 78.6 \%, 73.2 \%$, respectively). School principals were significantly more aware of restricted items than the canteen managers. The only marketing technique noted during school-based assessments was that two principals from one region reported corporate sponsorship by a pharmaceutical company during the academic year; the sponsorship involved the provision of follow-up milk formula and juices for school-related events.

All school canteens and 37 shops within 500 metres

\begin{tabular}{|c|c|}
\hline \multicolumn{2}{|c|}{$\begin{array}{l}\text { Table } 2 \text { Placement of advertisements on TV and in print } \\
\text { media }\end{array}$} \\
\hline Placement of advertisement & $\%(n)$ \\
\hline \multicolumn{2}{|l|}{ Television $(n=461)$} \\
\hline Between programmes & $72.7(335)$ \\
\hline During Children's cartoon film & $13.2(61)$ \\
\hline During Children's song & $11.5(53)$ \\
\hline During an entertainment programme & $2.6(12)$ \\
\hline \multicolumn{2}{|l|}{ Print media $(n=258)$} \\
\hline Sports supplement & $27.9(72)$ \\
\hline Advertisement supplement & $21.7(56)$ \\
\hline Economic supplement & $17.8(46)$ \\
\hline News section & $12.4(32)$ \\
\hline Local news page & $10.1(26)$ \\
\hline First page & $5.8(15)$ \\
\hline Children's section & $1.2(3)$ \\
\hline Others & $3.1(8)$ \\
\hline
\end{tabular}

of selected schools (including cafés, restaurants and convenience stores) were assessed for the types of products sold to students. In schools, managers perceived that a majority of beverages bought by students were those with added sugars such as drinks and juices (49.5\%) and milk-based drinks (22.8\%), items restricted under the MoE regulations. Ready-made food, which includes

Table 3 Percentage of school principals and canteen managers aware of items not to be sold in school canteens

\begin{tabular}{lcc} 
Restricted items & $\begin{array}{c}\text { School } \\
\text { principals }\end{array}$ & $\begin{array}{c}\text { Canteen } \\
\text { managers }\end{array}$ \\
\hline Fruit drinks (less than 30\% fruit juice) & 94.6 & 92.9 \\
Carbonated drinks & 100 & 100.0 \\
Energy drinks & 96.4 & 94.6 \\
Tang \& Vimto & 92.9 & 87.5 \\
Chocolate drinks & 80.4 & 78.6 \\
Potato chips and fries & 92.9 & 94.6 \\
Corn puffs & 82.1 & 76.8 \\
Sweets & 78.6 & 75.0 \\
Chocolates & 76.8 & 78.6 \\
Samosa (all types) & 92.9 & 92.9 \\
Ice cream & 87.5 & 83.9 \\
Seeds & 87.5 & 83.9 \\
Chewing gum & 87.5 & 85.7 \\
Puff pastry filled with jam, cheese or honey & 64.3 & 62.5 \\
Coconut bread & 75 & 73.2 \\
Cheese filled pastry with sugar syrup & 64.3 & 62.5 \\
Traditional desserts & 78.6 & 73.2 \\
Sausage, liver, burger sandwiches & 85.7 & 83.9 \\
\hline
\end{tabular}


high levels of salt, sugar and fat, were the most common food item sold. Restricted sugary food products were also reported to be popular, making up more than a quarter $(29.1 \%)$ of all items purchased by children. A very small proportion of the items purchased were fresh fruits and vegetables (4.5\%).

Students visited 23 of the 37 restaurants and convenience stores to/from schools. Store managers stated that soft drinks and juices were the most common drinks purchased. Like in schools, ready-made food and sugary food products were also popular; a negligible proportion purchased fresh fruits and vegetables.

The most common strategies in the 11 major grocery stores visited were discount schemes like the provision of free samples, games or gifts, "buy two get one free" or "get two at a lower price" schemes and winning shopping vouchers. Other techniques included using a cartoon figure on packaging, billboards, banners and displaying advertisements for a product. A high proportion of these advertised products were those with added sugars (i.e., chocolates and other sweets, breakfast cereals, cakes, sweet biscuits and cookies and soft drinks and juices).

\section{Discussion}

This rapid assessment was the first attempt to map the marketing of foods and non-alcoholic beverages to children in Oman. Results indicate that food and beverages high in fat, sugar and/or salt are being marketed to children through mass media channels and are widely available and popular in both school canteens and retail stores. Sugary drinks, in particularly, are among the most popular items bought by children from these outlets. Although a relatively high proportion of school principals and canteen managers were aware of the MoE regulations, several restricted items are being purchased by children from school canteens.

\section{Marketing of foods and beverages in mass media and food outlets}

The type of products advertised and the techniques used varied by type of mass media. TV advertising, the most common form of marketing globally $(10,23)$, was mostly for follow-up formula. Advertisements on the radio were largely for savoury snacks and fresh and frozen meats, while advertisements for sugary foods and drinks were more common in the print media. Globally, studies have focused on television advertising; they reported product variation by countries but also confirmed that advertisements for noncore foods dominated during children's programmes $(10,23)$. The ubiquitous advertising of savoury snacks targeting children on Omani radio channels and sugar-laden foods in retails stores reflects a similar phenomenon, and dominance of noncore foods in advertisements targeting children.

The most common techniques used, particularly in the local media, were the presence of children and the use of pictures, sounds and words that would attract children. Marketing techniques seen globally such as entertainment, competitions and the blurring of the boundary between television programmes and advertising breaks were not common, particularly in the local media $(10,23)$. The strict regulatory framework, especially as it relates to advertising and publishing (24), may have a dampening effect not only in print media but also the limited advertising seen in the larger retail stores. The numerous discount schemes in retail stores and other marketing techniques, however, raise concern. Further research is needed on children's exposure to these techniques and their impact on children's food preferences, purchase behaviours, food consumption and diet related health in Oman (10).

\section{Marketing of foods and beverages in schools}

Our findings show a lack of adherence to the current sales restrictions in school canteens which reflect both lack of awareness and a weak monitoring system. Sponsoring of school-based activities, although limited, is concerning. The sponsoring of events, anti-literacy initiatives, obesity prevention programmes, and installing vending machines are some of the strategies increasingly used by the food and beverage industry to target school-aged children globally $(25,26)$, including in low and middle-income countries $(10,27)$. Strengthening the MoE regulations along with a monitoring system would help control marketing practices for unhealthy food and ensure better quality of food and beverages for children during school hours.

\section{Policy implications}

This rapid assessment confirmed the need to establish a comprehensive regulatory framework in-line with the WHO recommendations on the marketing of foods and non-alcoholic beverages to children (6); it should be part of a comprehensive package of interventions to promote healthy eating and address childhood obesity in Oman. The Oman Child Law, passed by Royal Decree in 2014, serves as a basis for this framework (13). It should focus on reducing children's exposure to unhealthy food marketing and on restricting the use of marketing techniques that are particularly effective with children (13). These regulations should apply to all children below 18 years of age and cover all communication channels, settings and marketing techniques.

It should also expand the Publication Law's (21) definition of marketing by explicitly defining marketing to children according to product, timing, viewing audience, placement and content of the marketing message and the food that falls within the scope of marketing restrictions using the Regional Nutrient Profile (18). Strengthening the school-based regulations on the promotion and marketing of unhealthy foods and beverages is urgently required. It should be complemented by efforts to increase food and beverage literacy and their impact on children's health with principals, teachers, canteen managers and the community $(28,29)$.

Although not the focus of this assessment, the findings suggest strengthening monitoring the Oman 
Code for Marketing of Breast Milk Substitutes in-line with WHO and the WHO NetCode guidelines $(30,31)$. Research to assess the impact of legislation is critical to determine the most useful legislative interventions so as to guide policy-makers in the country (29).

Beyond the national agenda, three inter-related issues stand-out: food standards, marketing of breastmilk substitutes and satellite television. Oman and neighbouring countries are highly dependent on food imports (29) and the GCC functions as a common market. Setting a GCC-wide regulatory framework can counter the ineffectiveness of voluntary measures by the food and beverage industry (32) and the potential negative health effects of market liberalization, a key driver of obesity (33-35). In addition, the GCC Standardization Organization (GSO), which already provides standards for food, nutrition labelling and transfat $(36,37)$ should align standards to the WHO marketing recommendations (13).

The prominent advertising of follow-up milk formula observed on Pan-Arab satellite television is not surprising. The amount spent on advertising on these channels has increased significantly in recent years (13), and it will probably continue to expand. Sales of commercial breastmilk substitutes is skyrocketing and the 2008 total sales is expected to double to $10.8 \mathrm{~kg}$ per infant/child/year by 2018 (38). Promotion of follow-up formula is a violation of the International Code on the Marketing of Breastmilk Substitutes (30,38). Developing regional solidarity through the GCC, the Arab League and the Arab States Broadcasting Union would be a key step in addressing the marketing of unhealthy foods and beverages to children.

\section{Limitations}

This quick assessment of marketing techniques of the food and beverage industry was limited to traditional media channels, main retails stores and schools and depended on outlet managers' recall of children's purchasing patterns. It did not include private schools $(<10 \%$ of all schools in the country) and preschools where the situation may be different. Although this study did not involve a random sampling of food outlets, it is noteworthy that the inclusion of government schools and key retail stores throughout the country, as well as the most commonly viewed media channels in both Arabic and English, provide a glimpse of the current situation in Oman. However, the findings cannot be generalized; being the first study in Oman, it can serve as a baseline for further work in this area. Our evidence should be supplemented with research regarding marketing practices in social media and other venues where children may be targeted (i.e., fast food restaurants and sports facilities).

\section{Conclusion}

The food industry has a responsibility to ensure that its marketing practices respect all the rights and legal obligation to protect children in Oman, including the right to the highest attainable standard of health, the right to adequate food and other related human rights under the National Child Law. Urgent efforts are needed to establish a comprehensive regulatory framework based on the Child Law in-line with the WHO recommendations and as part of a comprehensive approach to promote healthy eating and prevent childhood obesity. Strengthening regulations should be complemented by efforts to increase food/beverage literacy and their impact on children's health with principals, teachers, canteen managers and the wider community as well as establishing a framework to monitor these regulations. Because GCC states are highly dependent on food imports and function as a common market, GSO food standards could be further enhanced. Regional solidarity through the GCC, the Arab League and the Arab States Broadcasting Union should work on addressing the marketing strategies used in Pan-Arab satellite channels.

Funding: None.

Competing interests: None declared.

\section{Évaluation rapide de la commercialisation d'aliments malsains auprès des enfants dans les médias de masse, les écoles et les magasins de vente au détail à Oman}

\section{Résumé}

Contexte : La prévalence du surpoids et de l'obésité est élevée dans la Région de la Méditerranée orientale. La moitié des femmes adultes de la Région (50,1\%) et plus de deux hommes sur cinq (43,8\%) sont en surpoids ou obèses; $6,9 \%$ des enfants de moins de cinq ans de la Région sont déjà en surpoids, ce qui est supérieur à la moyenne mondiale de 6,2\%.

Objectifs : La présente évaluation rapide visait à examiner les techniques de commercialisation des aliments et des boissons non alcoolisées destinés aux enfants et à évaluer l'application des restrictions alimentaires dans les écoles dans le cadre de l'effort national de lutte contre l'obésité à Oman.

Méthodes : Entre novembre 2015 et octobre 2016, des examinateurs formés ont évalué les stations de télévision par satellite arabes, la radio locale et la presse écrite, un échantillon aléatoire d'écoles et un échantillon de commodité d'épiceries, de cafés et de magasins de proximité. 
Résultats : La majorité des publicités télévisées (71 \%) portaient sur le lait relais et utilisaient diverses méthodes pour attirer les enfants. Une grande partie des publicités radiophoniques (44 \%) portaient sur des collations salées; toutes faisaient intervenir des enfants et utilisaient des mots et des sons pour les attirer. Peu de publicités dans la presse écrite faisaient la promotion de collations ; cependant, une grande majorité des publicités pour des collations sucrées ( $13 \%$ de la presse écrite) utilisaient des images/mots et des incitatifs (prix) pour attirer les enfants. Dans les écoles, la plupart des boissons achetées par les enfants contenaient des sucres ajoutés.

Conclusion: La mise en place d'un cadre réglementaire complet en vertu de la loi nationale sur l'enfance et de la Convention relative aux droits de l'enfant devrait être complétée par un suivi systématique de leur impact sur la santé de l'enfant et par un renforcement des connaissances en matière d'alimentation et de boissons chez les directeurs, les enseignants, les responsables de cantine et la communauté dans son ensemble.

التقييم السريع لتسويق الأغذية غير الصحية للأطفال في وسائل الإعلام والمدارس ومحلات البيع بالتجزئة في غُحَان

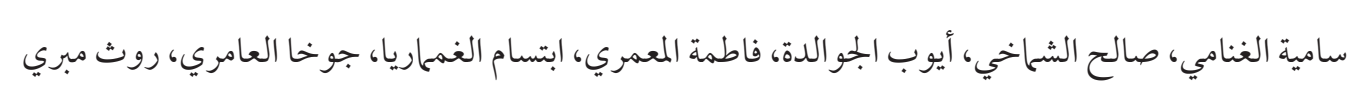

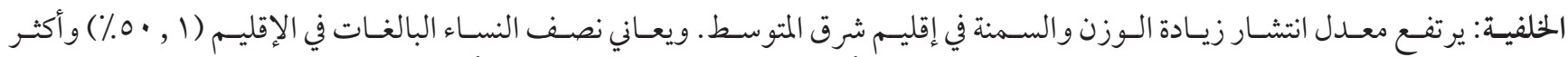

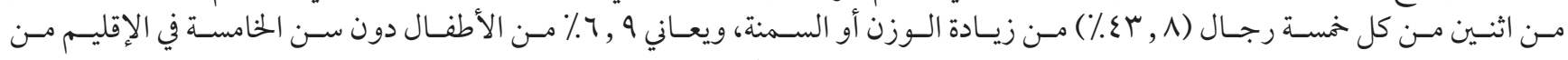

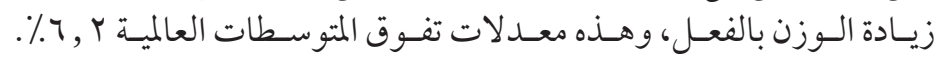

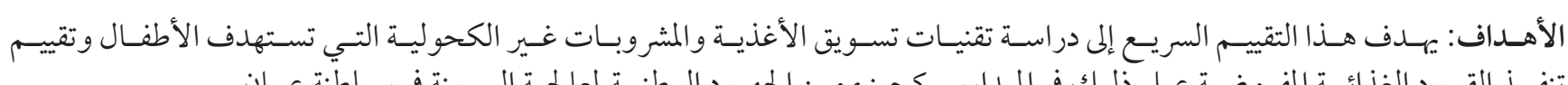

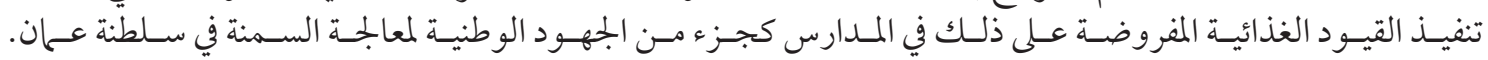

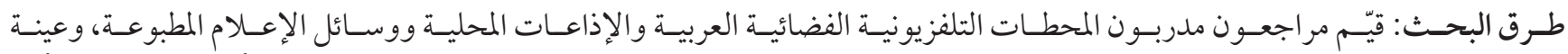

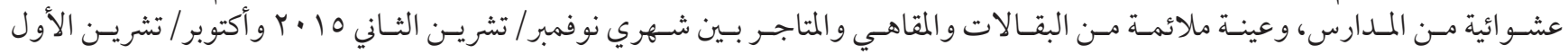

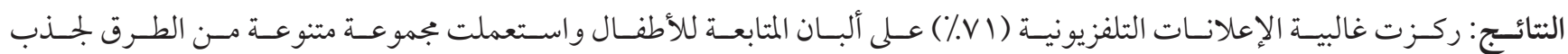

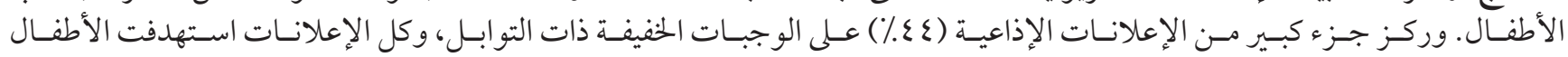

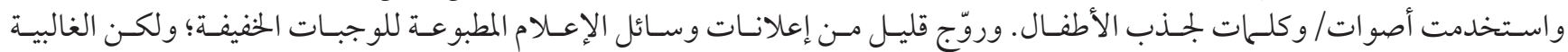

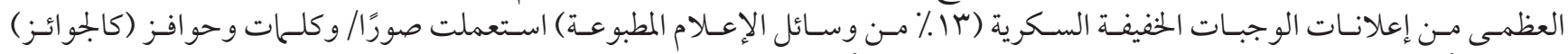

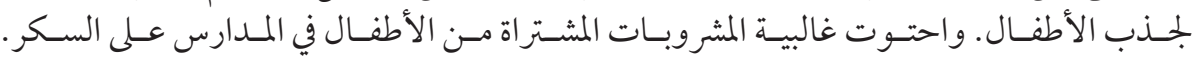

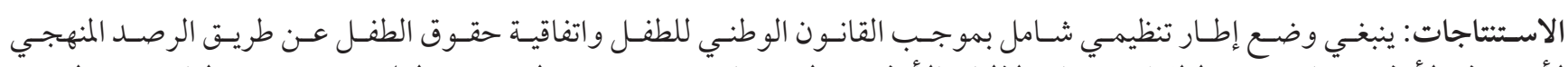

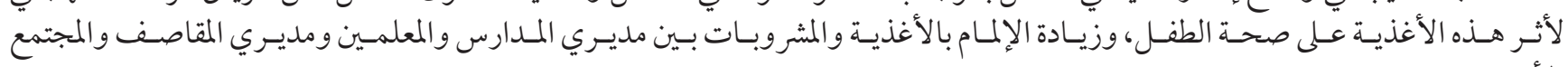

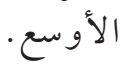

\section{References}

1. World Health Organization, Global Report on Diabetes. World Health Organization: Geneva; 2016.

2. Abdul-Rasoul MM. Obesity in children and adolescents in Gulf countries: facts and solutions. Avances en diabetologia, 2012. 28(3):64-69.

3. World Health Organization. Consideration of the evidence on childhood obesity for the Commission on Ending Childhood Obesity: report of the ad hoc working group on science and evidence for ending childhood obesity. World Health Organization: Geneva; 2016.

4. Pizzi MA, Vroman K. Childhood obesity: effects on children's participation, mental health, and psychosocial development. Occupational Therapy in Health Care. 2013; 27(2):99-112.

5. World Health Organization. Global Action Plan for the Prevention and Control of Noncommunicable Diseases, 2013-2020 [Resolution WHA66.10]. World Health Organization: Geneva; 2013.

6. World Health Organization. Set of recommendations on the marketing of foods and non-alcoholic beverages to children. World Health Organization: Geneva; 2010.

7. United Nations. Private Sector Should Stop Marketing Unhealthy Foods to Children, Urges Secretary-General in Message to Meeting on Non-Communicable Diseases. New York: United Nations; 2014. 
8. World Health Organization. Resolution 61.3 Noncommunicable diseases: scaling up implementation of the Political Declaration of the United Nations General Assembly. Cairo: World Health Organization Regional Office for the Eastern Mediterranean; 2014.

9. World Health Organization. Montevideo roadmap 2018-2020 on NCDs as a sustainable development priority. Geneva: World Health Organization; 2017.

10. Cairns G, Angus K, Hastings G, Caraher M. Systematic reviews of the evidence on the nature, extent and effects of food marketing to children. A retrospective summary. Appetite, 2013. 62: p. 209-215.

11. World Health Organization. Implementing the WHO recommendations on the marketing of food and non-alcoholic beverages to children in the Eastern Mediterranean Region. Cairo: WHO/EMRO; 2018.

12. UNICEF and Save the Children. Children's rights and business explained. Geneva: UNICEF and Save the Children; 2015.

13. World Health Organization. WHO mission report, National training workshop to build legal capacity to implement the set of WHO recommendations on the marketing of foods and non-alcoholic beverages to children. 2017.

14. Handsley E, Coveney J, Mehta K, Nehmy C. A children's rights perspective on food advertising to children. The International Journal of Children's Rights, 2014;22(1):93-134.

15. Osman YF, et al. Progression of obesity among Seeb school children in Oman. A preliminary study. Saudi medical journal, 2004. 25(12):2038-2040.

16. World Health Organization and Oman Ministry of Health, Global School Health Survey, Oman Fact Sheet, 2015. 2017.

17. Ministry of Health Oman. Annual Health Report, 2016. 2017, Director of Health Information and Statistics, Directorate General of Planning, Ministry of Health, Muscat: Ministry of Health; 2017.

18. Alasfoor DH, Rajab H, Al Rassasi B. Food Based Dietary Guidelines, Technical background and description, Oman Ministry of Health, Editor. Muscat: Ministry of Health; 2007.

19. World Health Organization and Ministry of Health Oman. Global School Health Survey, Oman Country Report, 2010. Muscat: Ministry of Health; 2010.

20. Al-Shaqsi OS. Readership and Readers' Perception of Omani Newspapers. Global Media Journal: American Edition, 2013.

21. National Centre for Statistics \& Information, Education statistics. 2017.

22. WHO Regional office for the Eastern Mediterranean Region. Draft regional nutrient profile model for marketing food and non-alcoholic beverage to children in the WHO Eastern Mediterranean Region. (unpublished)

23. Kelly B, Halford JCG, Boyland EJ, Chapman K, Bautista-Castano I, Berg C, et al. Television food advertising to children: a global perspective. American journal of public health, 2010. 100(9):1730-1736.

24. Curtis. Compliance with advertising regulations. 201417 October 2017] (http://omanlawblog.curtis.com/2014/04/compliance-with-advertising-regulations.html).

25. Matthews AE. Children and obesity: a pan-European project examining the role of food marketing. European journal of public health, 2007. 18(1):7-11.

26. Terry-McElrath YM, Turner L, Sandoval A, Johnston LD, Chaloupka FJ. Commercialism in US elementary and secondary school nutrition environments: trends from 2007 to 2012. JAMA pediatrics, 2014. 168(3):234-242.

27. Hawkes C. The worldwide battle against soft drinks in schools. American journal of preventive medicine, 2010. 38(4):457-461.

28. Kelly B, King L, Baur L, Rayner M, Lobstein T. Monitoring food and non-alcoholic beverage promotions to children. obesity reviews, 2013. 14(S1):59-69.

29. Al-Bahlani S, Mabry R. Preventing non-communicable disease in Oman, a legislative review. Health Promot Int, 2014. 29 Suppl 1:i83-ig1.

30. Grummer-Strawn LM, Zehner E, Stahlhofer M, Lutter C, Clark D, Sterken E, et al. New World Health Organization guidance helps protect breastfeeding as a human right. Maternal \& Child Nutrition, 2017. 13(4).

31. World Health Organization, Information concerning the use and marketing of follow-up formula. Geneva: World Health Organization; 2013.

32. Galbraith-Emami S, Lobstein T. The impact of initiatives to limit the advertising of food and beverage products to children: a systematic review. Obesity Reviews, 2013. 14(12):960-974.

33. Igumbor EU, Sanders D, Puoane TR, Tsolekile L, Schwarz C, Purdy C, et al. "Big food," the consumer food environment, health, and the policy response in South Africa. PLoS Med, 2012. 9(7):e1001253.

34. Monteiro CA, Cannon G. The impact of transnational "big food" companies on the South: a view from Brazil. PLoS Med, 2012. 9(7):e1001252.

35. Rahim HF, Sibai A, Khader Y, Hwalla N, Fadhil I, Alsiyabi H, et al. Non-communicable diseases in the Arab world. Lancet, 2014. 383(9914):356-67.

36. GCC Standardization Organization, Trans Fatty Acids. 2013.

37. GCC Standardization Organization, Requirements of nutritional labelling. 2012.

38. Baker P, Smith J, Salmon L, Friel S. Global trends and patterns of commercial milk-based formula sales: is an unprecedented infant and young child feeding transition underway? Public health nutrition, 2016. 19(14):2540-2550 